\title{
An overview of the Foreign and Security Policy of the European Union
}

\author{
* Dr. Muhammad Tariq, Lecturer \\ ** Amjad Ali Khan, Lecturer \\ *** Ejaz Khan, Visiting Lecturer
}

\begin{abstract}
The European Union comprises 27 countries that aim at carving out a separate foreign and security policy for their unification and singleness. The whole union is a symbol of unity and cohesiveness for which the theory of bargain provides the basic framework. This article focuses on the elements of the European Union's external policy, the principles and policy of the European Union, the foreign policy, security strategy, and the common foreign and security policy coupled with the defense strategy of the European Union. It also aims at describing the coherence and consensus of the EU on all important measures with particular reference to foreign and security policy and importance in the world as a global actor.
\end{abstract}

Keywords: Foreign, Security, Policy, European Union

\section{Introduction}

The European Union comprises 27 member states that have evolved a common foreign and security policy of its own. In the modern era, the role of the European Union (EU) has become recently significant in carving out an independent foreign, security and defense policy that make it a single and independent unit in the world. The significance of the EU can be gauged from the fact the United States and most of the major powers in the world look at the EU for partnership and cooperation on an extensive range of global issues (Mix, 2013). Both the United States and the EU share similar values on international politics, security, and economy that bring them closer towards cooperation and coordination. Observers are of the view that the joint efforts and work in a particular area can help in achieving efficacious results when seen through the common intercontinental and corresponding actions.

Since coming into existence in 1957 through the Treaties of Rome that led to the integration of the European countries it has been playing the most significant role in the survival and subsistence of the member countries. Owing to the integration of the member states under the umbrella of the EU, there has been the shift of policies from the individual states to the common institutions of the EU based in Brussels (Belgium) (Mix, 2013). It has served as a global actor with a key role in the affairs of the EU member states. Being one of the strongest actors in the international arena that has been making progress in the toughest form undergoing through the developed countries of Europe to the Commonwealth European countries for achieving a higher level of socio-economic progress and prosperity (Oleksly \& Cuza, 2016). The European Union speaks one in all affairs of the world. It allows the member states to resolve all challenges uniformly and particularly those challenges that cannot be tacked by them single-handedly (Union, 2019).

The foreign policy of the European Union also evolves under impact from both the structural and political and external geopolitical trends. But it is also a great reality that the foreign policy of the European Union is an inexplicit concept, depending on a dynamic contention of the EU itself. Researchers and scholars from Central and European Europe, particularly Poland, criticize the EU Eastern policy, which according to their opinion has inconsistency, incoherence, ideological differences, and has a declarative character. Some researchers are even critical of the European Union neighborhood policy on account of the lack of the vista of the relationship and inactive monetary aid as well as it fails in taking into description the essentials of the separate countries in the region (Oleksly \& Cuza, 2016).

* Department of Political Science, Hazara University Mansehra Email: tariqawkum252@ gmail.com

** Department of Political Science, Hazara University Mansehra

*** Department of Political Science, Hazara University Mansehra 
Understanding the foreign and security policies of the European Union is not an easy job but presents a challenge for the true understanding and comprehension regarding its relations with other countries and non-member states (Archick, 2020). There have been changes in the foreign and security policies of the EU from time to time as per the needs and requirements of the modem time. For this purpose, various treaties were signed in different decades to show its rejuvenation and vitality. The modern European Union got its birth in 1992 under the Treaty on European Union also known as the Maastricht Treaty whereby the external policies of the EU have been formulated and managed under the following institutional processes:

$>\quad$ The Common Foreign and Security Policy (CFSP), comprising a Common Security and Defence Policy (CSDP), describes the status of the member states in intergovernmental nature. The European Council provides the member states the opportunity to act in an agreedupon and consensus-based way where they are represented by their respective heads of states or governments. The other forum is the Council of European Union, where the Council of Ministers ensure their representation, and is like the European Council, an important key actor. The Common Security and Defence Policy is carried out after getting the consensus of all the member states. The role of the heads of states and government is very important in getting the consensus and resolving all the issues related to the security paradigm of the EU.

External policies are shaped in such areas as trade, foreign assistance, and the expansion of the EU concerning its formulation and execution of the decision-making procedures in the domains of the EU bodies. Of all these, the role of the European Commission is very significant in dealing with the important matters and has a great role in the decision making power of the EU. So, the external policies pertain to the trade, commerce, foreign aid, and enlargement of the EU, which are put into practice by the European Commission.

Due to lack of coherence and consensus, the Lisbon Treaty was signed in December 2009 that brought about drastic changes in the basic structure for making improvements in the coherence and efficacy of the external policies for the enhancement of coordination between the two strands of creating coherence and effectiveness. The said treaty aimed at strengthening the two paradigms of coherence and effectiveness by establishing harmony and smoothness by removing the discordant elements. The treaty aimed at improving upon the three weaknesses identified by the analysts while dealing with the outdoor strategies and process of making policies of the European Union.

Firstly, the lack of consensus on many issues including the political agreement among the 27 member states on specific issues cannot be achieved readily. Divergence of opinion amongst the member countries of the EU can lead to the weakness of the union resulting in the sparsely settled policy or no common policy at all that will be consented over by all the participant countries of the European powers. So, the nonexistence of agreement and course can put obstacles in the way of reaching an agreed-upon policy for the whole union.

Secondly, some critics assert time and again that the foreign policy of the European Union tends to suffer from insufficient institutional coordination and coherence. This is based upon the view that the transnational and worldwide components of external policy had not been linked in a harmonious or complementary way.

Thirdly, former official arrangements ----namely, the former prominence of the rotating sixmonth national presidencies in external affairs, were susceptible to shifting priorities, with results sometimes harmful to the continuity of the policy. The shifting in presidencies within just a period of six-month is not useful for the smooth functioning of the EU. It leads to inconsistency and abrupt changes of primacies of policies by the various actors as members of the office.

\section{The Principles of the $\mathbf{E U}$}

Since the very birth of the European Union during the 1950s, it has been able to regard itself as a civilian power. North Atlantic Treaty Organization (NATO) is the only proper forum where it can focus on the serious issues of the Cold War, defense, and security parameters of the member states. During the embryonic stages, its main concern was the preoccupation with the integration of the economy. This integration remained concerned with the aspect of cooperation among the sovereign states that showed antithesis with the power politics, leading twice to the devastation of the European power in 1914 and 1945 (Mix, 2013). But the turning point was the end of the Cold War era that provided the European powers with the opportunity of carving out a uniformed foreign policy. It was 
during the 1990s that Europe was able to build an EU security and integrity coupled with the defense capability (Bindi, 2012).

\section{The European Security Strategy}

Released in 2003, the European Security Strategy (ESS), is another milestone of the European Union that helps in understanding the cardinal philosophy of the foreign policy of the EU (Brussles, 2003). The ESS carves out three basic principles and objectives for the policymakers of the European Union:

a. Firstly, the EU has to take necessary action for addressing a considerable list of global challenges and security threats, comprising the conflicts at the regional level, propagation of weapons of mass destruction, terrorist activities, failure of the state and system, prearranged crimes, diseases and the element of poverty that could destabilize the world.

b. Secondly, the European Union has to focus on the strengthening of security at the regional level in the neighborhood areas of the Balkans, the Caucasus, and the Mediterranean region, and the Middle East.

c. Thirdly, the EU has to seek the establishment of a rules-based, multifaceted global order, whereby the strong regional and global institutions can help in ensuring the international law, peace, and security in the region.

The role of the European Union is very significant in dealing with the challenges and threats faced at the global level. It also aims at resolving all the outstanding issues concerning the region and particularly the weapons of mass destruction and steps necessary to eradicate the elements of terrorism from the globe. In this paradigm, the main objective of the EU is to bring stability to the region and take steps for reducing poverty and do away with the destabilization of the region. For providing coherence and strength to the regional powers, the pivotal point rests upon strengthening the grey areas by making them more secure and safe. It is for security that the areas of Balkans, the Caucasus, and the Mediterranean region are given special attention for keeping protected. Another important perspective of the EU is the creation of a rules-based multilateral world where law is supreme and where peace and security should reign supreme.

It is also significant to mention that the challenges and threats faced by the European Union cannot be addressed by military means and coercive measures only but it does take into account a combination of measures comprising the political, military, and economic enterprises. This may encompass diplomacy, peaceful means necessary for the resolution of disputes, geopolitical strategies, and economic sanctions. The combination of these three measures can result in better prospects for the resolution of disputes and getting the threats and challenges addressed in a more sophisticated way (Bengtsson, 2008). For this purpose, the EU tries to reach the root cause of the conflict and instability and focusing on strengthening the system of governance at all levels.

\section{The Common Foreign and Security Policy}

The Treaty of 1992 on the European Union made efforts to establish the CFSP formally for smooth and harmonious operation of the EU. The CFSP covers within its purview the global concerns of a dogmatic and consular nature with a specific focus on the security or military orientation (Mix, 2013). The treaty not only focused on the single paradigm of foreign policy but also dealt with the security and military orientation of the EU. The treaty also makes provisions for the 27 member states of the EU with the prerogative powers to make political and security policies based on close cooperation and coordination. The main concern of all the member states is to reach a consensus on any given issue or policy-making process (Joseph, 2004). Here, the role of the member states is to work as a single team with the sole aim of being agreed on all the important matters concerning the foreign and security policies. It is also pertinent to mention that no single state has the power and prerogative to impose its will or decision over the rest of the member states.

\section{The Role of Institutions and Actors}

The basic institutions of the European Union are the European Council comprising the heads of states or governments of the member states and the Council of Ministers or the Council of the European Union. These two play the most important and defining role in the foreign and security policies of the EU. The European Council is the highest organ of political activity and meets twice during the period of every six months under the nomenclature of the "EU Summit" but it can also meet more than twice in case of emergency and extraordinary circumstances. The European Council has the responsibility for the identification of the tactical benefits and goals of the Union concerning the practical action. So, the main organ of the EU has to play a key role in defining the strategic interests and objectives in 
so far as external action is concerned. It is the only organ that provides a platform for providing political direction and gives the choice of priorities in shaping the Common Foreign and Security Policy. The European Council is headed by a President whose main task is to manage its work, facilitate consensus, and help ensure the continuity of policies, besides being, the chief spokesman of the council. The President is also assisted by the Vice President, also called the High Representative, who participates in the affairs of the EU and is responsible for submitting the suggestions of CFSP for considerations.

Another important forum responsible for the development of political consensus and direction is the Council of Ministers, it is here that most of the mechanism of decision making power of the CFSP is put into practice. The Foreign Ministers of 27 member countries meet once a month for discussing important matters concerning the foreign policy of the member states. For any decision regarding the CFSP decision to be made, it requires unanimity among all the member states and consensus but any foreign minister may veto a measure (Mix, 2013). The High Representative as a president of the Foreign Affairs Council also chairs the Foreign Affairs Council, for creating and facilitating consensus among the members of the group. This council, in collaboration with the European External Action Service, has the responsibility to manage, implement, and represent CFSP decisions. The Political and Security Committee (PSC) gives support to the High Representative and the Foreign Affairs Council. The Political and Security Committee which is also called the Council structure, comprises ambassadors from the member states. The main function of the PSC is to monitor and assess the international concerns having relevance to the CFSP. It also provides input into the decision-making process of the CFSP by monitoring and implementing the CFSP (Batt \& Lynch, 2003). For this purpose, both the PSC and the High Representative work in close collaboration with each other and dependent upon each other for any important decision.

Four main elements comprehensively describe the CFSP. These include the Principles and Guidelines, Common Strategies, Joint Actions, and the Common Positions. The Principles and Guidelines is an important organ of the CFSP since it focuses on the strategic objectives and interests of the European Union and give practical shape and framework to the policies and actions of the EU. The strategic decisions after being agreed upon by the EU leaders regarding the CFSP are promulgated in the form of conclusions and results after receiving the approval of the European Council or the Foreign Affairs Council (Union, 2020). The European Security Strategy which mainly aims at preventing the production of the dangerous arms meant for destructive purposes (2003), the strategy used for countering the terrorism and insurgency adopted by the European Union (2005), and the security strategy which is used for maintaining internal peace (2010), also fall within the domain of the Principles and Guidelines.

Subsequent activity formalizing the status of agreed concepts are triggered by the high-level political direction. The Common Positions and Joint Action which signify the decisions on common position and joint actions are the other two important elements that provide strength to the CFSP (Cardwell, 2009). The instrument of Common Positions deals with the objectives of the European Union and concentrate on a jointly agreed diplomatic approach concerning a specific region or state. This may better be explained by the EU's position on Cuba as many of the observers in the United States ascribe it to this type of Common Position but the EU has also taken recourse to adopt such a Common Position to countries like Zimbabwe, Belarus, and North Korea. Such types of CFSP decisions are used by the EU for addressing any problematic situation, where the foreign states do not comply with the norms and values of International Law.

Another important instrument of the CFSP is the Joint Action that pertains to launch or extend a civilian or military operation in an out-of-area territory under the CSDP. In the bygone days, such ventures comprised the employment of EU Special Representatives (EUSR), assignment of senior diplomats to a sensitive country or region to give the EU an additional political thump. A Joint Action may help in providing financial or other relevant sustenance to the assigned activities of the international organization involved in non-proliferation, for example, the International Atomic Energy Agency (IAEA), or peacekeeping, for example, the Organization for Security and Cooperation in Europe.

\section{The Common Security and Defence Policy}

The operational arm of the CFSP is the Common Security and Defence Policy that gives practical manifestation to the security and defense measures of the European Union. It was in 1999 that the 
member countries of the EU agreed to initiate work on a cohesive security and defense policy under the auspicious patronage of the EU. The accomplishments of the CSDP are not just military in nature, despite the martial and security elements of the policy. It is significant to mention that the operational activities of the CSDP also consist of civilian activities comprising police and judicial training and measures for reforming the security sector. It has shown its potential in the activities of peacekeeping, conflict resolution and prevention, management of crisis, post-conflict stability, missions on humanitarian grounds, rather than conventional military combat operations.

The policy formulators and decision-makers of the EU have been trying to develop a more established CSDP by providing it with the enhancement and coordination of the soldierly potentialities of the member states (Mix, 2013). Steps have been taken for improving the military strength and potential of the European Union to make the defense system stronger and viable. It was for this purpose that in 2004, the European Defence Agency (EDA) was created to coordinate the defense-industrial and procurement policy for stretching the European defense expenditure. An important parameter of the CSDP is concerned with the creation of an autonomous EU potentialities for conducting external operations. The CSDP does not intend to develop rivalry or competition with NATO but intends to be a complementary alternative.

\section{Financing System of the CFSP}

The financial system is the backbone of any institute or organization and provides the basis for running and working of the system. Since the EU is a global organization of the 27 member states and requires huge capital for organizational purposes and smooth functioning. Financing of the CFSP is cohesively associated with the decision-making unit and the consensus-based measures (Hooijer, 1994). It includes the administrative costs and day to day expenditures of the CFSP. For any financial expenditure, the joint consensus of the Council is very much essential which must show the unanimity of opinion among the various members of the council. It is necessary to mention that the financial expenditure of the EU is run and organized through the 'Community Budget'. The financial framework of the EU was outlined in 2006 when it received approval from the European Parliament (Bendiek \& Whitney, 2006). Due to the huge strength of the structure of the EU, it is not always easy to get consensus among all the member states and challenges may stand in the way of unity and singleness of decisions. Some of the challenges may include the lack of transparency in getting the funds allocated, lesser possibility of having control over the allocation of resources as is done in the democratic set-up, the specification of funds for specified areas, and the element of insufficiency in the allotment of funds.

It is an important fact that finance forms an integral part of the CFSP for providing a complete feeding mechanism to the whole EU (Parenti, 2020). The internal market system gets strengthened under the auspicious patronage of unrestricted transfer of amenities and investment. To get the system more integrated, more efforts have been taken to streamline the financial mechanism which encompasses doing away the removal of the national entry barriers, steps to harmonize the local laws and rules of the concerned states, steps for improving the internal market system of the member states, creation of the single currency system throughout the whole of Europe, steps for reforming the financial crisis and making further improvements which are in line with the harmonious functioning of the CFSP.

\section{Conclusion}

The European Union is an important global actor having its separate autonomous entity concerning its foreign policy and security policy. The EU is such an important entity that the United States and the major powers want to have close collaboration and coordination with it. The common policy shows the singleness and unity of the union in most of the important matters. Being a group of twenty-seven countries, the EU has been able to develop a collective influence under the common nomenclature of CFSP. The aspect of CFSP includes within its ambit the CSDF which represents the transnational relations of the member countries. The two basic organs of the EU are the European Council represented by the heads of state or governments and the Council of European Union which is also known as the Council of Ministers.

Keeping in view, the strength of the various states it is also important to note that the CFSP of the EU suffers from certain inherent flaws. The most important one is the elements of consensus which it has not achieved since there is usually a lack of consensus on most of the outstanding issues among the various member states. A general perception has got developed that has made it a forum of 
group indicating, "speaks with many voices". Another important flaw in the way of unity among the member states is the lack of institutional adhesion and coordination. It has led to the delinking of the intergovernmental and supranational strands of external policy in a harmonious way. The third element is the prior institutional arrangement resulting in the six-month national presidencies on a rotational basis is another area of great concern, which again is a step towards inconsistencies of policies and priorities.

But there is no gainsaying the fact that the European Union is a global actor that has emerged as a civilian power while NATO has been considered as the device for maintaining security and defense measures among the member states. It is also important to dilate upon the fact that NATO has been the only forum for defense issues since the 1950s. The most significant thing about the European Union is that the operational arm of the Common Foreign and Security Policy is the Common Security and Defence Policy. It means that the Common Security and Defence Policy are the two organs of the CFSP that is responsible for the smooth and harmonious operation of the European Union.

There is no denying the fact that finance is the very soul of a system and provides sound foundations for the success or failure of a policy. Similarly, the CFSP of the European Union is also dependent upon the financial resources for its success since it comprises the 27 member states. The resources of finance are spent after getting the consensus developed among the member states. There must be coherence and agreed-upon policies for the expenditure of the capitals by the CFSP but certain limitations do put a hindrance in the way of spending over the specified areas. Some of the key challenges that stand in the way of incoherence include the defining line of an area, the specification of funds, the allocation of funds, and the problem of insufficiency of funds.

\section{References}

Archick, K. (2020). The European Union: Questions and Answers.

Batt, J., \& Lynch, D. (2003, September ). Partners and Neighbours: a CFSP for a wider Europe. Institute for Security Studies.

Bendick, A., \& Whitney, H. (2006, June 16). The Financingo of the EU's Common Foreign and Security Policy. Stiftung Wissenschaft und Steele Politk, German Institute for International and Security Affairs. Retrieved from https://www.swp-berlin.org/en/publication/financing-eus-cfsp/

Bengtsson, R. (2008, November 5). Constructing Interfaces: the Neighbourhood Discourse in EU External Policy. Journal of European Integration, 30(5). Retrieved from https://www.tandfonline.com/ doi/abs/10.1080/07036330802439582

Bindi, F. (2012). "European Union Foreign Policy: A Historical Overview," in The Foreign Policy of European Union, ed.Foderiga Bindi and Irina Angelescu. Washington DC, United States: The Brooking Institution.

Brussles. (2003, December 12). "A Secure Europe in a Better World-European Security Strategy, Retrieved from https://eclan.eu/en/eu-legislatory/a-secure-europe-in-a-better-world-europeansecurity-strategy.

Cardwell, P. J. (2009). EU, External Relations and Systems of Governance. Abingdon, United Kingdom: Routledge.

Hooijer, F. F. (1994). The Common Foreign and Security Policy of the European Union. European Commission, 184. Retrieved from www.ejil.org>pdfs

Joseph S. Nye, J. (2004). Soft Power: The Means to Succeed in World Politics. New York, United States: Public Affairs.

Mix, D. E. (2013). The European Union: Foreign and Security Policy. Congressional Research Service. Congressional Research Service.

Oleksly, K., \& Cuza, A. L. (2016). Foreign Policy of the European Union: Eurasian Agenda. 8(3), 348363. Retrieved from http://hdl.handle.net/10419/198466

Parenti, R. (2020, November). Financial Services Policy: Fact Sheets on the European Union. Retrieved from https://www.europarl.europa.eu/factsheets/en/sheet/83/financial-services-policy.

Union, E. (2020, July ). European Council Conclusions. Retrieved from COuncil of the European Union.

Union, P. o. (2019, 9 17). Foreign Affairs and Security Policy. Retrieved from https://op.europa.eu/en/publication-detail/-/publication/9d4c3b27-d82c-11e9-9c4e-01aa75ed71a1. 